\title{
Editorial note on recurrent themes and a call for special issues
}

Journal of International Relations and Development (2004) 7, 355.

doi:10.1057/palgrave.jird.1800033

In this issue, Breitenbauch and Wivel analyze the development of the discipline of International Relations (IR) in Denmark. JIRD has a tradition of publishing articles on national IR disciplines. It started with Alexander Sergounin's analysis of IR in Russia and Petr Drulák and Radka Druláková's take on the IR discipline in the Czech Republic (both in JIRD 2000/3). Later, Jörg Friedrichs analyzed IR theory in France (JIRD 2001/2) and Lucarelli and Menotti criticized the development of the discipline in Italy (JIRD 2002/2).

With the publication of Alex MacLeod's article on French foreign policy in this issue, we would like to initiate another 'recurrent theme' on national foreign policy traditions to which we invite manuscript submissions.

$J I R D$ also publishes special issues, usually once a year. We would like to make an open call to guest editors for submissions of such an issue. The submission should include not just titles and abstracts, but a full package of first drafts. It is on the basis of this package that the editorial team will compare proposals and make its decision by mid-year. All special issues go through the usual peer-reviewed process.

The Editors 